\title{
Irritable bowel syndrome immune hypothesis. Part one: the role of lymphocytes and mast cells
}

\author{
M. Ortiz-Lucas ${ }^{1}$, P. Saz-Peiró ${ }^{1}$ and J. J. Sebastián-Domingo ${ }^{2}$ \\ ${ }^{1}$ Department of Microbiology, Preventive Medicine and Public Health. University of Zaragoza. ${ }^{2}$ Digestive System Unit. \\ Hospital Royo Villanova. Zaragoza, Spain
}

\begin{abstract}
Objective: To review the available evidence on the role of $\mathrm{T}$ lymphocytes and mast cells in the etiopathogenesis of Irritable Bowel Syndrome.

Methods: Bibliographic retrieval on PubMed including the terms "Irritable Bowel Syndrome, "Immune System", "T-Lymphocytes" and "Mast Cells".

Results: Twenty-five case-control studies and one randomized controlled trial were retrieved. Noteworthy in the blood is the increase in activated $\mathrm{T}$ cells destined to migrate to the bowel in these patients. A high frequency of T-lymphocytes is described in the intestinal mucosa, although the study findings are, at times, contradictory. An evident increase in mast cells (and in their activity) between the terminal ileum and descending colon is also observed.

Conclusions: The heterogeneity of diagnostic criteria and experimentation methods could account for some of the differences in the results found in the selected research. There are indications that give reason to believe these patients have "low-grade intestinal inflammation", and the increase in T-lymphocytes and mast cells has been associated with disorders found in IBS such as the communication between the intestine and the nervous system, the increase in intestinal permeability and changes in the microbiota.
\end{abstract}

Key words: Irritable bowel syndrome. Immune system, T-lymphocytes. Mast cells. Psychoneuroimmunology. Systematic review.

M. Ortiz Lucas, P. Saz Peiró, J. J. Sebastián Domingo. Irritable bowel syndrome immune hypothesis. Part one: the role of lymphocytes and mast cells. Rev Esp Enferm Dig 2010; 102: 637-647.

Received: 22-01-10

Accepted: 20-04-10.

Correspondence: María Ortiz Lucas. Medicina Preventiva. Facultad de Medicina - Aulario B. C/ Domingo Miral s/n. 50009 Zaragoza, Spain. e-mail: mariaortizlucas@gmail.com

\section{RESUMEN}

Objetivo: Revisar la evidencia disponible sobre el papel de los linfocitos T y mastocitos en la etiopatogenia del Síndrome del Intestino Irritable. de las vías biliares.

Métodos: Recuperación bibliográfica en PubMed incluyendo los términos "Irritable Bowel Syndrome, "Immune System", "T Lymphocytes" y "Mast Cells".

Resultados: Se recuperaron 25 estudios casos-control y un ensayo clínico aleatorizado. A nivel sanguíneo destaca el aumento de células $\mathrm{T}$ activadas destinadas a migrar al intestino en estos pacientes. En la mucosa intestinal se describe un patrón elevado de linfocitos $\mathrm{T}$, aunque los resultados de los estudios son en ocasiones contradictorios, y un aumento claro de mastocitos (y de su actividad) entre el íleon terminal y colon descendente

Conclusiones: La heterogeneidad de criterios diagnósticos y de métodos de experimentación podría explicar algunas de las diferencias en los resultados que se encuentran en las investigaciones seleccionadas. Existen indicios que conducen a pensar que existe una "inflamación intestinal de bajo grado" en estos pacientes, y se ha relacionado el aumento de linfocitos $\mathrm{T}$ y de mastocitos con trastornos encontrados en el SII como la comunicación entre el intestino y el sistema nervioso, el aumento de la permeabilidad intestinal y los cambios en la microbiota.

Palabras clave: Síndrome del Intestino Irritable. Sistema inmune. Linfocitos T. Mastocitos. Psiconeuroinmunología. Revisión sistemática.

\section{INTRODUCTION}

In April 2009, a group of specialist doctors from the Hospital "Royo Villanova" in Zaragoza set up the "Functional Digestive Disorders and Psychoimmunology Research Group" within the framework of the Biomedical Research Map of the Aragon Institute of Health Sciences.

Our objective is to investigate the relationships which exist between Functional Digestive Disorders (FDD), particularly Irritable Bowel Syndrome (IBS), and Psychoneuroimmunology (PNI). 
Prior to pursuing our lines of research, we carried out a series of Evidence-Based Systematic Reviews (EBSR), the first of which concerns the probable immune hypothesis of IBS, whose results are outlined in the present article and subsequent article.

IBS constitutes a functional disorder of the small and large intestine characterized by abdominal pain/discomfort, meteorism with abdominal distension and alterations in bowel movements with a predominance of diarrhea, constipation or alternating diarrhea/constipation, which cannot be explained by structural or biochemical abnormalities (1). It is estimated that approximately $3 \%$ of primary care consultations and between $16 \%$ and $25 \%$ of gastroenterology consultations are due to this condition (2).

Its etiopathogenesis and pathophysiological mechanism are unknown. Several pathogenic factors responsible for IBS have been suggested, such as genetic and environmental factors (3), alterations in digestive motility (4), visceral hypersensitivity (5), inflammatory and postinfection mechanisms (6), psychological morbidity (7), physical and sexual abuse (8) and bacterial overgrowth (9), among others. However, none of them seem to clearly explain the real mechanisms that trigger the syndrome. The most recent theories point to the fact that the possible interaction between all the factors involved in IBS (psychology, visceral hypersensitivity, immunology, intestinal immune system, microbiota and probiotics) could be understood and explained from the field of PNI (10).

PNI is an interdisciplinary scientific field dedicated to the study and investigation of the interaction and communication mechanisms between the brain (mind/behavior) and the systems responsible for the homeostatic maintenance of the organism, the nervous (central and autonomic), immunological and neuroendocrine systems, as well as their clinical implications (11).

Within this context, the objective of this Systematic Review (SR) is to assess the available evidence on the role of the immune system in the etiopathogenesis of IBS.

\section{METHODS}

The bibliographic search was undertaken on the PubMed database (www.pubmed.gov) until December 2009. In the research strategy the MeSH terms "Irritable Bowel Syndrome, "Immune System", "T-Lymphocytes" and "Mast Cells" were employed. The research was not restricted to any type of specific investigation given that our objective, to study the etiopathogenesis of the disorder, made it necessary to compile not only clinical trials but also observational studies $(12,13)$.

In the SR, studies which fulfilled the following criteria and confines were included: the study of a set of patients with IBS in association with a control group (CG) and/or other pathologies; reference made to the etiopathogenesis of IBS from the standpoint of a probable immune hypothesis; studies undertaken on humans, and articles published in Spanish or English. Excluded were those articles in which no relationship was found with said probable hypothesis and those conducted on animals.

The entire text of the article was acquired if, having read the title and/or summary, there was an indication it could fulfill the selection criteria. Once the entire text of the article was read, it was decided whether or not it would be chosen for its final assessment.

The methodological quality of the articles was assessed in line with the recommendations of the Cochrane Collaboration. Nevertheless, said recommendations seek to assess the validity of clinical trials and cannot be applied in the same manner as observational studies (13). The objective when assessing the methodological quality was not whether to afford a global assessment of the study's degree of validity or not, but rather to objectively determine the most noteworthy methodological aspects in the studies retrieved.

In order to analyze the findings it was considered whether the determination of the immune components was conducted by means of a blood test and/or biopsy, differentiating the intestinal area in which it was performed, and, secondarily, whenever possible, it was analyzed whether there were differences between the different subtypes of IBS (diarrhea [D], constipation [C], alternating [A]), or between the form of onset of the disorder (post-infectious [PI], non-PI).

\section{RESULTS}

A total of 26 valid articles related to the probable immune hypothesis of IBS were retrieved. One of them constitutes a randomized controlled trial (RCT) (14) and the remaining 25 are case-control studies (15-39). The RCT has great methodological validity, although it does not refer to the sample representativeness (14).

In all the articles the patient immune profile was examined by means of performing a blood test $(15,25,28,30,31,38,39)$ and/or a biopsy of one or more parts of the intestine $(14,16-24,26-37,39)$. The IBS diagnosis was made according to Rome I Criteria $(14,18,19,22)$, Rome II Criteria $(20,21,23-26,28-32,34,35,37-39)$ or Rome III Criteria $(33,36)$, with the exception of one that employed the Rome Criteria together with the Manning Criteria (27). In the two 1993 studies, the Manning Criteria (16) and clinical symptoms (15) were employed. Two studies make use of the Rome Criteria but it was not possible to determine which of them $(17,27)$.

The researchers followed different criteria when studying IBS. Some studies selected all the patients with IBS without taking IBS subtypes into account $(15,25,27,38)$. Others differentiated between patients 
with PI-IBS and patients with non-PI-IBS $(14,18,21-$ $23,28,31)$ and, the last studies differentiated patients according to the predominance of symptoms $(14,16,17,19-22,24,26,28-37,39)$. Despite differentiating between the different pathology subtypes, the majority of the studies did not have a sufficient sample size so as to establish significant differences in the immune profile between the subsets. Three studies exclusively selected patients with PI-IBS $(14,18,22)$-one of which chose, in turn, patients with post-dysenteric IBS (18)-, one study selected patients with non-PI-IBS (33) and four studies chose patients with D-IBS $(20,29,30,32)$. The main characteristics of the articles retrieved are outlined in table I.

\section{Lymphocytes}

Lymphocytes are responsible for specific immune responses. These are divided into B-lymphocytes, which produce antibodies and are responsible for the antibody response to antigens; and T-lymphocytes, responsible for cell-mediated immune responses and other cooperation functions for all forms of immune response to take place. Lymphocytes are morphologically indistinguishable; therefore, membrane immunoglobulin ( $\mathrm{mlg}$ ) markers are used to differentiate between B-lymphocytes and the T-Cell Antigen Receptor CDS-Complex (TCR)-CD3 for T-lymphocytes. Moreover, there is a high number of human leukocyte differentiation antigens, otherwise known as clusters of

Table I. Characteristics of the studies retrieved

\begin{tabular}{|c|c|c|c|}
\hline $\begin{array}{c}\text { Study, } \\
\text { year (reference) }\end{array}$ & $\begin{array}{l}\text { Diagnostic crite } \\
\text { Participants: num }\end{array}$ & $\begin{array}{l}\text { ria and IBS type } \\
\text { ber, gender, age }\end{array}$ & Intervention and Outcome Assessment \\
\hline $\begin{array}{l}\text { Swiatkowski, } \\
1993 \text { (15) }\end{array}$ & $\begin{array}{l}\text { Clinical symptoms (abnormal } \\
\text { bowel habit and abdominal } \\
\text { pain) and negative physical } \\
\text { and laboratory findings. } \\
\text { IBS: } 74 \text { (F: } 51, \text { MA: 44) }\end{array}$ & CG: 15 (F: 9, MA: 39) & $\begin{array}{l}\text { Blood test. } \\
\text { Total number of lymphocytes and T-lymphocytes. } \\
\text { Zung Depression Self-Rating Scale. }\end{array}$ \\
\hline Spiller, 2000 (18) & Rome I Criteria & CE: 21 (F: 13, MA: 50) & $\begin{array}{l}\text { Rectal biopsy: PD-IBS: } 8 \text { - } 48 \text { months after their initial } \\
\text { episode. CE: subsequent to diagnosis and } 6 \text { and } 12 \text { weeks } \\
\text { after. } \\
\text { Enteroendocrine cells, MC, CD3, CD4 and CD8 lympho- } \\
\text { cytes, IE lymphocytes, lamina propria macrophages } \\
\text { (CD68), lamina propria calprotectin, gut permeability: lac- } \\
\text { tulose/mannitol ratio. } \\
\text { Bowel Symptom Questionnaire, SF-36, Adverse life event } \\
\text { questionnaire. }\end{array}$ \\
\hline
\end{tabular}

(Continúa en la página siguiente) 
Tabla I. Characteristics of the studies retrieved (Cont.)

\begin{tabular}{|c|c|c|c|}
\hline $\begin{array}{l}\text { Study, } \\
\text { year (reference) }\end{array}$ & $\begin{array}{l}\text { Diagnostic criteri } \\
\text { Participants: numb }\end{array}$ & $\begin{array}{l}\text { ria and IBS type } \\
\text { ber, gender, age }\end{array}$ & Intervention and Outcome Assessment \\
\hline $\begin{array}{l}\text { Dunlop, 2003a } \\
\text { (14) }\end{array}$ & $\begin{array}{l}\text { Rome I Criteria } \\
\text { TG: } 14 \text { (F: 6, MA: 40.1 SD3.0). } \\
\text { CG: } 15 \text { (F: 9, MA: 38.3 SD2.8). } \\
\text { PI-IBS-D: 22, PI-IBS-C: 2, } \\
\text { PI-IBS-A: } 5\end{array}$ & & $\begin{array}{l}\text { Clinical trial: An initial and a final evaluation } 6 \text { weeks later } \\
\text { were carried out. 2-week run-in period, followed by } 3 \text { weeks } \\
\text { of treatment and a further week without treatment prior } \\
\text { to the second assessment. } \\
\text { TG: prednisolone } 30 \mathrm{mg} / \text { day at breakfast time. } \\
\text { CG: placebo. } \\
\text { Rectal biopsy. } \\
\text { EC, lamina propria T-lymphocytes. } \\
\text { Gastrointestinal Symptom Rating Scale, IBSQoL, Modified } \\
\text { Talley Bowel Symptom, HADS, Global score of well-being. }\end{array}$ \\
\hline $\begin{array}{l}\text { Dunlop, 2003b } \\
\text { (21) }\end{array}$ & $\begin{array}{l}\text { Rome II Criteria } \\
\text { PI-IBS: } 23 \text { (F: 13, MA: } 38.1 \\
\text { SD2.6); PI-IBS-D: 16, PI-IBS-C: } \\
\text { 2, 2, PI-IBS-A: } 6 \\
\text { Non-PI-IBS: } 52 \text { (F: 40, MA: } 40.3 \\
\text { SD1.9); Non-PI-IBS-D: 22, Non- } \\
\text { PI-IBS-C: 17, Non-PI-IBS-A: } 13\end{array}$ & $\begin{array}{l}\text { CG: } 36 \text { (F: 19, MA: } 45.3 \\
\text { DE3.3) } \\
\text { 3 }\end{array}$ & $\begin{array}{l}\text { Rectal biopsy. } \\
\text { Symptom duration, days per week of pain, days per week } \\
\text { of loose stool, days per week of hard stool, proportion } \\
\text { with urgency. } \\
\text { EC, lamina propria T-lymphocytes, IE lymphocytes, MC. } \\
\text { HADS. }\end{array}$ \\
\hline $\begin{array}{l}\text { Dunlop, } 2003 c \\
\text { (22) }\end{array}$ & $\begin{array}{l}\text { Rome I Criteria } \\
\text { Patients with campylobacter } \\
\text { infection } 3 \text { months previously. } \\
\text { Patients diagnosed with IBS } \\
\text { prior to the infection were } \\
\text { excluded: } \\
\text { PI-IBS: } 30 \text {; IBS-D: } 68 \% \text {, IBS-C: } \\
4 \%, \text { IBS-A: } 28 \%\end{array}$ & $\begin{array}{l}\text { CG: } 28 \\
\text { Those who did not develop } \\
\text { PI-IBS after the infection. } \\
\text { HG: } 34\end{array}$ & $\begin{array}{l}\text { Rectal biopsy. } \\
\text { EC, lamina propria T-lymphocytes, lamina propria } \\
\text { MC, IE lymphocytes. } \\
\text { Gastrointestinal Symptom Rating Scale, IBSQoL, Modified } \\
\text { Talley Bowel Symptom, HADS, Global score of well-being }\end{array}$ \\
\hline Wang, 2004 (23) & $\begin{array}{l}\text { Rome II Criteria } \\
\text { IBS: } 56 \text { (F: 31, MA: 43.3); : } \\
\text { PI-IBS 27, Non-PI-IBS: } 29\end{array}$ & GC: 12 (F: 7, MA: 43.4) & $\begin{array}{l}\text { Biopsy from the terminal ileum and rectosigmoid junction. } \\
\text { junction. } \\
\text { mRNA expression of IL-1 } \alpha, I L-1 \beta \text { and IL-1ra (receptor } \\
\text { antagonist). } \\
\text { MC, MC, nerve fibres: NSE (Neuron-Specific Enolase), SP, } \\
\text { 5-HT, CGRP (Calcitonin Gene-Related Peptide). }\end{array}$ \\
\hline $\begin{array}{l}\text { Elsenbruch, } 2004 \\
(25)\end{array}$ & $\begin{array}{l}\text { Rome II Criteria } \\
\text { IBS: } 14 \\
\text { (F: 14, MA: } 47.7 \text { SD3.6) }\end{array}$ & $\begin{array}{l}\text { GC: } 14 \\
\text { (F: 14, MA: } 40.0 \text { SD2.6) }\end{array}$ & $\begin{array}{l}\text { Fasting patients ingested } 500 \mathrm{ml} \text { of Fresubin (a chocolate- } \\
\text { flavoured, standardised liquid nutrition solution containing } \\
\text { a total of } 500 \mathrm{Kcal} \text { ) within a 10-minute time frame. The ba- } \\
\text { seline data were collected and, subsequent to the ingestion } \\
\text { of Fresubin, } 4 \text { postprandial periods were completed, the first } \\
\text { had a 15-minute duration and the remaining periods had a } \\
\text { 30-minute duration. Blood samples were taken following } \\
\text { each period. } \\
\text { CD3+, CD3+CD4+ and, CD3+CD8+ lymphocytes, NK cells } \\
\text { (CD3-CD16+CD56+ lymphocytes), B cells (CD3-CD20+ } \\
\text { lymphocytes), monocytes (CD14+ leukocytes), granulocytes, } \\
\text { TNF- } \alpha \text { and IL-6 production in vitro, norepinephrine, cortisol, } \\
\text { prolactin. } \\
\text { Blood pressure, heart rate. } \\
\text { Gastrointestinal Symptoms Questionnaire, STAl, SCL-90-R } \\
\text { (Symptom Checklist-90-Revised). }\end{array}$ \\
\hline
\end{tabular}


Tabla I. Characteristics of the studies retrieved (Cont.)

\begin{tabular}{|c|c|c|c|}
\hline $\begin{array}{c}\text { Study, } \\
\text { year (reference) }\end{array}$ & $\begin{array}{l}\text { Diagnostic } \\
\text { Participants: }\end{array}$ & $\begin{array}{l}\text { ria and IBS type } \\
\text { ber, gender, age }\end{array}$ & Intervention and Outcome Assessment \\
\hline Dong, 2004 (26) & $\begin{array}{l}\text { Rome II Criteria } \\
\text { IBS-D: } 22 \text { (F: 12, MA: 36) } \\
\text { IBS-C: } 20 \text { (F: 12, MA: 41) }\end{array}$ & CG: 19 (F: 19, MA: 34) & $\begin{array}{l}4 \text { biopsies from the terminal ileum, ileocecal junction and } \\
\text { sascending and sigmoid colon. Anorectal manometry } \\
\text { Rectal test, sensation threshold, defecation threshold, pain } \\
\text { threshold and rectal compliance. } \\
\text { MC, SP-ergic terminals. }\end{array}$ \\
\hline
\end{tabular}

\begin{tabular}{ll}
\hline Tunc, 2005 (27) & Rome and Manning Criteria \\
& IBS: 11 (F: 3, MA: 46.4 \\
& SD16.5)
\end{tabular}

IBD: 5 (F:1 MA: 41.6 SD9.8) Cecal biopsy. SD16.5)

CG:5 (F:2, MA: $50.4 \quad$ Mucosal MC.

Öhman, 2005 Rome II Criteria UC: 23 (F: 10,

(28)

IBS: 33 (F: 19, MA: 42 SD12); MA: 42 SD11).

IBS-D: 20 (4 with PI-IBS),

IBS-C: 4 (1 with PI-IBS),

Patients with UCr y UCa.

IBS-A: 9

CG: 15 (F: 7, MA: 53 SD8)

\begin{tabular}{ll}
\hline Park, 2006 (29) & Rome II Criteria \\
& IBS-D: 18 (F: 8, MA: 42.6)
\end{tabular}

\begin{tabular}{lll}
\hline Guilarte, 2007 & Rome II Criteria & CG: 14 (F: 6, MA: \\
& IBS-D: 20 (F: 14, MA: & 27.9 SD7.8) \\
& 32.8 SD7 7) &
\end{tabular}

32.8 SD7.7)

Newly diagnosed patients.

CG: 15 (F:5, MA: 41.4)

8 biopsies from the ascending and sigmoid colon, blood test.

Lamina propria lymphocytes.

Linfocitos de la lámina propia.

Peripheral blood lymphocytes.

MAdCAM-1+ (mucosal addressin cell adhesion molecule-1), IFN- $\gamma$, CD4+, CD8+, Int $\beta 7$, CD45RA.

le-1), IFN- $\gamma, C D 4+$, CD8+, Int $\beta 7$, CD45RA.
8 biopsies from the terminal ileum, ascending colon and
rectum.

Mucosal MC, infiltrations of plasma cells, lymphocytes, eosinophils and neutrophils.

Questionnaire regarding bowel symptoms, BDI, STAI.

Jejunal biopsy, fluid content aspirate, blood test.(30)

IE lymphocytes, MC, jejunal luminal tryptase and tryptase concentration in serum.

Spanish version of the "Holmes-Rahe Modified Social Readjustment Scale", BDI, the Irritable Bowel Severity Scoring System.

\begin{tabular}{|c|c|c|c|}
\hline $\begin{array}{l}\text { Holmén, } 2007 \\
\text { (31) }\end{array}$ & $\begin{array}{l}\text { Rome II Criteria } \\
\text { IBS: } 34 \text { (F: 24, MA: } 40 \text { SD13); } \\
\text { IBS-D: } 21 \text { (3 with PI-IBS), } \\
\text { IBS-C: } 2 \text { (1 with PI-IBS), } \\
\text { IBS-A: } 11\end{array}$ & $\begin{array}{l}\text { GC: } 26 \\
(F: 13, M A: 53 \text { SD10) }\end{array}$ & $\begin{array}{l}\text { Ascending and sigmoid colon biopsies, blood test. } \\
\text { Blood and colonic lamina propria CD4+CD25+ } \\
\text { regulatory T cells. } \\
\text { FOXP3 mRNA levels. }\end{array}$ \\
\hline $\begin{array}{l}\text { Remes-Troche, } \\
2007 \text { (32) }\end{array}$ & $\begin{array}{l}\text { Rome II Criteria } \\
\text { IBS-D: } 10 \text { (F: 9, MA: } 43 \text { SD3) }\end{array}$ & $\begin{array}{l}\text { CD: } 12 \text { (F: 7, MA: } 45 \text { SD5) } \\
\text { SIBO: } 8 \text { (F: 5, MA: } 55 \text { SD4) }\end{array}$ & $\begin{array}{l}5 \text { biopsies from the distal part of the duodenum, duodenal } \\
\text { aspirate. } \\
\text { Total number of epithelial cells, total number of IE lymp- } \\
\text { hocytes, } \gamma \delta+\text { IE lymphocytes, CD3-CD7+ and CD45RO+. }\end{array}$ \\
\hline Wang, 2007 (33) & $\begin{array}{l}\text { Rome III Criteria } \\
\text { IBS-D: } 20 \\
\text { (F: 12, MA: } 48.7 \text { SD16.6) } \\
\text { IBS-C: } 18 \\
\quad \text { (F: 9, MA: } 41.5 \text { SD15.1) }\end{array}$ & $\begin{array}{l}\text { GC: } 20 \\
(F: 11, M A: 39.3 \text { SD19.5) }\end{array}$ & $\begin{array}{l}6 \text { biopsies from the terminal ileum, descending part of the } \\
\text { duodenum and proximal end of the jejunum. } \\
\text { EC, 5-HT, MC. }\end{array}$ \\
\hline Piche, 2008 (35) & $\begin{array}{l}\text { Rome II Criteria } \\
\text { IBS: } 50 \text { (F: 41, MA: } \\
\text { 53.8 SD12.0); IBS-D: } 21 \\
\text { (F: 16, MA: 54.5 SD12.2), } \\
\text { IBS-E: } 29 \text { (F: 25, MA: } 51.1 \\
\text { SD13.5) }\end{array}$ & $\begin{array}{l}\text { DG: } 11 \text { (F: 4, MA: } 58.8 \\
\text { SD7.9) } \\
\text { CG: } 21 \text { (F: 14, MA: } 56.5 \\
\text { SD9.5) }\end{array}$ & $\begin{array}{l}\text { Biopsies: } 4 \text { of } 10 \text { biopsies were taken from the cecum. } \\
\text { Biopsies were limited to the cecum in controls and in } \\
\text { depressed patients. } \\
\text { Bowel movements (number/week), severity of abdominal pain/ } \\
\text { discomfort, abdominal well-being. } \\
\text { Cellularity of the lamina propria, IE lymphocytes, MC, } \\
\text { lymphocytes, plasmocytes, eosinophils, neutrophils. } \\
\text { FIS (Fatigue Impact Scale), BDI. }\end{array}$ \\
\hline
\end{tabular}

(Continúa en la página siguiente) 
Tabla I. Characteristics of the studies retrieved (Cont.)

\begin{tabular}{|c|c|c|c|c|c|}
\hline \multirow{2}{*}{$\begin{array}{c}\begin{array}{c}\text { Study, } \\
\text { year (reference) }\end{array} \\
\text { Lee, } 2008 \text { (36) }\end{array}$} & \multicolumn{4}{|c|}{$\begin{array}{l}\text { Diagnostic criteria and IBS type } \\
\text { Participants: number, gender, age }\end{array}$} & Intervention and Outcome Assessment \\
\hline & \multicolumn{2}{|c|}{$\begin{array}{l}\text { Rome III Criteria } \\
\text { IBS: } 42 \text { (F: 25, MA: } 47.8 \\
\text { DE11.5) } \\
\text { PI-IBS: } 5 \text { (F: 4, MA: } 44.4 \\
\text { DE14.0) } \\
\text { Non-PI-IBS: } 37 \text { (F: 21, MA: } \\
\text { 48.1 SD11.2); IBS-D: } 17 \\
\text { (F: 8, MA: 49.7 SD12.2), } \\
\text { IBS-C: } 13 \text { (F: 8, MA: 44.2 } \\
\text { DE11.3), IBS-A: } 7 \text { (F: } 5, \\
\text { MA: 52.6 SD6.7) }\end{array}$} & \multicolumn{2}{|c|}{$\begin{array}{l}\text { CG: } 12 \text { (F: 5, MA: } 50.8 \\
\text { DE11.5) }\end{array}$} & $\begin{array}{l}2 \text { biopsies from the mid-rectum. } \\
\text { HADS, gastrointestinal symptom questionnaire. } \\
\text { EC, MC, lamina propria T-lymphocytes. }\end{array}$ \\
\hline $\begin{array}{l}\text { Cremon, } 2009 \\
\text { (37) }\end{array}$ & \multicolumn{2}{|c|}{$\begin{array}{l}\text { Rome II Criteria } \\
\text { IBS: } 48 \text { (F: 35, MA: } 42.7 \\
\text { DE14.8); IBS-D: } 27 \text { (F: 16, } \\
\text { MA: 43.5 SD13.6), IBS-C: } 21 \\
\text { (F: 19, MA: 41.6 SD16.4) }\end{array}$} & \multicolumn{2}{|c|}{$\begin{array}{l}\text { MCo: } 12 \text { (F: 9, MA: } 38.9 \\
\text { DE18.0) } \\
\text { UCr: } 10 \text { (F: 4, MA: } 44.6 \\
\text { DE16.6) } \\
\text { UCa: } 10 \text { (F: 5, MA: } 36.9 \\
\text { DE9.9) } \\
\text { CG: } 24 \text { (F: 15, MA: } 32.0 \\
\text { DE14.9) }\end{array}$} & $\begin{array}{l}4 \text { biopsies from the proximal descending colon. } \\
\text { CD3, CD4, CD8 T cells, CD79 B cells, MC. } \\
\text { BDQ. }\end{array}$ \\
\hline Kindt, 2009 (38) & $\begin{array}{l}\text { Rome II Criteria } \\
\text { IBS: } 30 \text { (F: } 80 \%, \mathrm{M}\end{array}$ & A: 37.0$)$ & \multicolumn{2}{|c|}{$\begin{array}{l}\text { FD: } 23 \text { (F: 83\%, MA: 39.0) } \\
\text { NCCP: } 15(F: 73 \%, \\
\text { MA: } 51.0) \\
\text { CG: } 32 \text { (F: 77\%, MA: 30.5) }\end{array}$} & $\begin{array}{l}\text { Blood test. } \\
\text { Allergy screening: validated questionnaire and RAST: } \\
\text { measurement of eosinophils and specific immunoglobulin } \\
\text { E (IgE) antibodies. } \\
\text { Measurement of cytokine production by lymphocytes: Perip- } \\
\text { heral blood mononuclear cells (PBMC): IL-5, IL-10, IL-13, } \\
\text { IFN- } \gamma \text {; Monocytes: TNF- } \alpha \text {, IL-10, IL-12; Serum: IL-6, IL-10. } \\
\text { Immunophenotyping. Markers: CD3, CD5, CD4, CD8, ratio } \\
\text { CD4/CD8, CD3+ CD25+, CD3+ HLADR+, D3+ CD11b+, } \\
\text { CD3+ CD69+, CD3+ CD28+, CD3+ CD45RA+, CD3+ } \\
\text { CD45RO+, CD4+ CD45RO+, CD4+ CD45RA+, CD3+ } \\
\text { CD45RA+ CD45R0+, CD3+ CD16+ CD56+, CD19, CD19+ } \\
\text { CD5+, CD3-CD16+CD56+. } \\
\text { HADS. }\end{array}$ \\
\hline $\begin{array}{l}\text { Öhman, } 2009 \\
\text { (39) }\end{array}$ & $\begin{array}{l}\text { Rome II Criteria } \\
\text { COHORT A: } \\
\text { IBS: } 74 \text { (F: 52, } \\
\text { MA: } 34 \text { SD16); } \\
\text { IBS-D: 26, IBS-C: } \\
\text { 11, IBS-A: } 37 \\
\text { CG: } 30 \text { (F: 20, } \\
\text { MA: } 39 \text { SD10) }\end{array}$ & $\begin{array}{c}\text { COHORT } \\
\text { IBS: } 26 \text { ( } \\
\text { MA: } 44 \\
\text { IBS-D: } \\
\text { IBS-C: } \\
\text { CG: } 14 \text { ( } \\
\text { MA: } 33\end{array}$ & $\begin{array}{l}\text { B: } \\
23, \\
\text { SD14); } \\
1, \\
\text { IBS-A: } 9 \\
\text { :10, } \\
\text { SD9) }\end{array}$ & $\begin{array}{l}\text { COHORT C: } \\
\text { IBS: } 11 \text { (F: 9, } \\
\text { MA: } 33 \text { SD9); } \\
\text { IBS-D: 4, IBS-E: 1, } \\
\text { IBS-A: } 6 \\
\text { CG: } 10 \text { (F: 7, } \\
\text { MA: } 41 \text { SD7) }\end{array}$ & $\begin{array}{l}\text { COHORTS A and B: } \\
\text { Blood test. } \\
\text { COHORT C: } \\
\text { Ascending and sigmoid colon biopsies. } \\
\text { Blood: Phenotype from T cells, CD4+ and CD8+ T cells, } \\
\text { CD4+ CD69+ and CD8+ CD69+ T cells, CD4 + Int } \beta 7+ \\
\text { HLA-DR+ and CD8+Int } \beta 7+H L A-D R+T \text { cells, CD4+ CD25+ } \\
\text { and CD8+ CD25+ T cells, CD4+ CD26L and CD8+ CD26L } \\
\text { T cells, CD4+ and CD8+ T cells proliferation. Stimulated } \\
\text { IL-2, IFN- } \gamma \text {, IL-10 and IL-1 } \beta \text { secretion. } \\
\text { Biopsy: CD4+ and CD8+ T cells proliferation, proliferation } \\
\text { of lamina propria T-lymphocytes in the ascending and sig- } \\
\text { moid colon. } \\
\text { Questionnaire: IBS Severity Scoring System. }\end{array}$ \\
\hline
\end{tabular}

A: Alternating; BDI: Beck's Depression Inventory; BDQ: Bowel Disease Questionnaire; C: Constipation; CD: Celiac disease; CE: Campylobacter enteritis; CG: Control group; D: Diarrhea; DG: Depression group; EC: Enterochromaffin cells; F: Females; FD: Functional dyspepsia; HADS: Hospital Anxiety and Depression Scale; HG: Healthy group; 5HT: Serotonin or 5-hydroxytryptamine; IBD: Inflammatory Bowel Disease; IBSQoL: Irritable Bowel Syndrome Quality of Life questionnaire; IBS: Irritable Bowel Syndrome; IE: Intraepithelial; IFN: Interferon; IL: Interleukin; Intק7: Integrin $\beta 7$; LC: Lymphocytic colitis; MA: Mean age; MC: Mast cells; MCo: Microscopic colitis; MI: Microscopic inflammation; NCCP: Non-cardiac chest pain; NH: Normal histology; NSI: Non-specific inflammation; PD: Post dysenteric; PI: Post-infectious; SD: Standard deviation; SIBO: Small intestinal bacterial overgrowth; SP: Substance P; STAI: State-Trait Anxiety Inventory; TG: Treatment group; TNF: Tumor necrosis factor; UC: Ulcerative colitis; UCa: UC active; UCr: UC in remission; 
differentiation (CD), which allow the differentiation and detection of the different lymphocyte subtypes (40).

Numerous CD are described but this review does not seek to refer to them. Nevertheless, reference will be made to those deemed relevant to the presentation of this review.

All T-lymphocytes express the CD3 marker and, in turn, are divided into CD4+ T cells, known as helper Tlymphocytes (Th lymphocytes), and CD8+ T-lymphocytes, known as cytotoxic T-lymphocytes. Both subtypes are differentiated functionally by their cooperation action in every type of immune response or by their cytotoxic action which causes cell lysis, respectively. Both CD4+ T-lymphocytes and CD8+ T-lymphocytes express the CD45 molecule (it participates in the activation of T-lymphocytes through the receptor (TCR-CD3), allowing, in turn, the isoform CD45RA or CD45RO to be expressed. The former refers to naïve lymphocytes, which have not been in contact with the antigen, and the latter refers to memory lymphocytes, which have previously been in contact with the antigen (41).

The chronic and repeated activation of Th lymphocytes gives rise to their differentiation into Th1 lymphocytes and Th2 lymphocytes. There are no phenotypic markers that identify these cells, which therefore calls for their in vivo culture as well as an analysis of the cytokines they produce in order to differentiate both subtypes (40).

\section{The role of lymphocytes in IBS}

Many studies have endeavored to ascertain whether or not a higher presence of lymphocytes or their various markers exists, which could differentiate the behavior of the various lymphocyte populations in patients with IBS.

1. Blood lymphocytes: $\beta 7$ integrin is a marker expressed in the T cells activated in the lymph nodes associated with the intestine and which mediates the migration of T-lymphocytes to the intestinal mucosa by means of binding to its ligand, the mucosal addressin cell adhesion molecule-1 (MAdCAM-1+), expressed in the endothelial cells of the gastrointestinal tract (28). HLA-DR is the receptor of the major histocompatibility complex II (MHCII), which is expressed in activated T cells. CD69 is the cell-surface marker expressed in the recent activation of T cells and CD25 is the IL-2 receptor chain, which is an indicator of cell activation. CD62 is the ligand, which is expressed in the naïve lymphocytes that circulate around the lymph nodes (39).

Regular levels of total lymphocytes, T-lymphocytes, CD4+ T-lymphocytes and CD8+ T-lymphocytes in the peripheral circulation of patients with IBS $(15,28,39)$ were found. Levels of cytotoxic $\mathrm{T}$ cells, helper $\mathrm{T}$ cells and $\mathrm{B}$ cells were observed in regular parameters subsequent to ingestion (25). However, on studying the T-lymphocyte markers, a higher frequency of CD4+ and CD8+
$\mathrm{T}$ cells was observed in peripheral blood expressing $\beta 7$ integrin (28) which, in addition, co-express HLA-DR. An increase in T cells expressing the CD69 marker is also described, but not those which express CD25 or CD62L (39).

Furthermore, an increase in levels of CD3+ CD45RA+CD45R0+ was found in patients in whom the disorder had appeared acutely, with regular levels in the remaining markers studied $(31,38,39)$.

There is a moderate negative correlation between the frequency of T cells with a high expression of CD25 ( $\alpha$ chain of the IL-2 receptor, indicator of cell activation) and bowel habit dissatisfaction and symptom severity, which leads us to believe that patients with more severe symptoms have a higher frequency of $\mathrm{T}$ cells expressing CD25 (39).

2. Intestinal lymphocytes: A high number of intraepithelial lymphocytes (IE lymphocytes) was found in the ascending, transverse and descending colon and in the rectum of patients with IBS, in patients under 35 years of age with a normal histology -both diarrhea-predominant or alternating- and in patients with a history of the disorder exceeding five years (19). A high number was also detected in the rectum of patients with post-dysenteric IBS (18) and in the jejunum of patients with IBS-D (30). However, Dunlop et al do not find differences in IE lymphocytes in the rectum between patients with PI-IBS and non-PI-IBS and the healthy population $(21,22)$, and levels of IE lymphocytes in the duodenum of patients with IBS-D were normal (32). Furthermore, no signs of a decrease in IE lymphocytes were presented on administering prednisolone or placebo (22).

In the lamina propria (LP), differences were not found in lymphocyte infiltration in the cecum, ascending colon, descending colon or in the rectum (17). However, Piche et al (35) find high levels of LP lymphocytes in the cecum of patients with IBS.

Similarly, a high number of T-lymphocytes were found in the LP of the rectum both in patients with PIIBS and patients with non-PI-IBS $(21,22)$. Lee et al (36) encountered said increase in T-lymphocytes in the rectum of patients with PI-IBS but not in those with non-PI-IBS. On comparing a group of patients with PIIBS with a CG of individuals who three months previously had had a campylobacter infection, and who had not developed IBS symptoms, differences in the number of T-lymphocytes in the LP of the rectum (22) were not found.

In patients with PI-IBS, a decrease in the number of lymphocytes in the LP of the rectum subsequent to the administration of oral corticosteroid was noted, although it was not significant as regards the reduction presented in the CG (14). When the colonic T cells were polyclonally stimulated, a lower proliferation of LP T-lymphocytes in the group with IBS was found, compared to the $\mathrm{CG}$, in the ascending colon but not in the sigmoid colon (39). 
An increase in $\mathrm{CD} 3+$ and $\mathrm{CD} 25+$ in the LP of the ascending, transverse and descending colon was described in patients with IBS, regardless of whether they present or not any degree of microscopic inflammation $(19,37)$, as well as an increase in CD4+ and CD8+ cells in the LP of the descending colon (37) and CD8+ in the ascending colon, but not in the sigmoid colon (28). Other studies, on the contrary, have not found said increase in CD4+ or CD4+CD25+ T cells in the LP of the ascending colon or the sigmoid colon of patients with IBS, in any of the subsets of these patients $(28,31)$. Nevertheless, of note is the fact that a subpopulation of more than $40 \%$ of patients with IBS was found with a frequency equal to or higher than $38 \%$ of CD4+ T cells in the LP, which is the highest ratio found with regard to the $\mathrm{CG}(28)$.

The patients in whom the symptoms appeared gradually had more CD25+ cells than those in whom the onset was acute. In addition, the number of CD3+ cells was higher in patients with IBS with a normal histology and in those with diarrhea-predominant or alternating IBS than those who had constipation-predominant IBS (19).

The patients with IBS had similar frequencies of CD4+ and CD8+ T cells that expressed $\beta 7$ integrin in the LP to the CG. Levels of MAdCAM-1+ in the ascending colon and sigmoid were higher in the group of patients with IBS, although in the sigmoid colon the differences with the CG were not significant (28).

All these findings, together with the increase in blood $\mathrm{T}$ cells which express the $\beta 7$ integrin, seem to indicate that patients with IBS have an increased frequency of circulating T cells destined to migrate to the intestine (28).

The majority (70-99\%) of all the isolated T cells in the mucosa of the ascending colon and the sigmoid colon had a CD45RA memory phenotype, whereas the distribution of naïve colonic cells (CD45RA+) in patients with IBS did not differ from the healthy subjects (28).

Other studies (34) find high levels of CD3 cells and regular levels of $\mathrm{CD} 4$ cells in these patients.

\section{Intestinal mast cells}

Table II outlines the mast cell (MC) profile in the intestine found in patients with IBS.

In the group of patients with IBS-D, the number of $\mathrm{MC}$ in the terminal ileum, ascending colon and rectum was higher in the group without rectal hypersensitivity than in the group with rectal hypersensitivity (29).

In patients with IBS an increase in the density of nerve fibers and $\mathrm{MC}$-in number and activity- which surround them was observed. In addition, in the IBS-D subset, the activation rate of said cells is higher in close proximity to enteric nerves than away from enteric nerves; said differences are not observed in the CG. The rate of MC degranulation was also higher.

By the same token, a positive correlation was found between the rate of MC degranulation and nerve-to-mast
Table II. Mast cell profile in IBS patients' bowel

\begin{tabular}{|c|c|c|}
\hline Part of the bowel & Regular levels & Increased levels \\
\hline Duodenum & $\begin{array}{l}\text { SII-D (33) } \\
\text { SII-E (33) }\end{array}$ & \\
\hline Jejunum & $\begin{array}{l}\text { SII-D (33) } \\
\text { SII-E (33) }\end{array}$ & SII-D (30) \\
\hline Terminal ileum & & $\begin{array}{c}\text { SII }(16) \\
\text { SII-D }(16,26,29,33) \\
\text { SII-E }(26,33) \\
\text { SII-PI }(23) \\
\text { SII-no PI }(23)\end{array}$ \\
\hline Ileo-cecal junction & & $\begin{array}{l}\text { SII-D (26) } \\
\text { SII-E (26) }\end{array}$ \\
\hline Cecum & & $\begin{array}{c}\text { SII }(17,27,35) \\
\operatorname{SIIID}(20)\end{array}$ \\
\hline Ascending colon & & $\begin{array}{c}\text { SII }(17) \\
\text { SII-D }(26,29) \\
\text { SII-E }(26) \\
\text { SII-IM (19) }\end{array}$ \\
\hline Transverse colon & & SII-IM (19) \\
\hline Descending colon & & $\begin{array}{c}\text { SII }(17,24,37) \\
\text { SII-IM }(19)\end{array}$ \\
\hline Sigmoid colon & $\begin{array}{l}\text { SII-D (26) } \\
\text { SII-E (26) }\end{array}$ & \\
\hline Rectosigmoid junction & $\begin{array}{c}\text { SII-PI (23) } \\
\text { SII-no PI (23) }\end{array}$ & SII (34) \\
\hline Rectum & $\begin{array}{c}\text { SII }(17) \\
\text { SII-PI }(21,22) \\
\text { SII-no PI }(36)\end{array}$ & $\begin{array}{c}\text { SII (36) } \\
\text { SII-D }(20,29) \\
\text { SII-PI (36) } \\
\text { SII-no PI (21) } \\
\text { SII-IM (19) }\end{array}$ \\
\hline
\end{tabular}

Study references are indicated in brackets. IBS: Irritable Bowel Syndrome, PI: Post-infectious, D: Diarrhea, C: Constipation, A: Alternating, MI: Microscopic inflammation.

cell proximity, and between the proximity of MC to nerves and both the severity and frequency of abdominal pain or discomfort $(20,23,24)$.

\section{CONCLUSIONS OF THE AUTHORS}

This review affords an overview of the levels of lymphocytes and MC in patients with IBS.

The fact that IBS is a FDD renders it difficult to establish a clear diagnostic criterion. The studies reviewed employed various criteria to select the target population, which can account for the differences encountered in their findings (the Rome II criteria are broader and include patients that the Rome I and Rome III criteria would exclude). Another factor that could explain these differences is the use of different laboratory techniques to measure cell levels.

Generally speaking, the sample sizes are not large and the studies do not perform calculations on the sample size 
according to statistical criteria, which does not allow a generalization of the findings for a general population to be reached. This can also applied to the extrapolation of the results in the different subsets of patients with IBS (D, C, A, PI, non-PI).

IBS is a disease in which, typically, alterations in intestinal motility and visceral hypersensitivity seemed to exist, apparently without any organic alteration. In the endoscopy, the intestinal mucosa is normal without macroscopic alterations. However, it seems that there are cell factors, which give reason to believe that there is low-grade intestinal inflammation in this pathology.

Furthermore, added to this are other elements such as the communication of the intestine with the nervous system, the increase in intestinal permeability and changes in microbiota that appear in these patients. In all these aspects, the high number of $\mathrm{T}$ cells and $\mathrm{MC}$ found in patients with IBS exerts an influence.

Study findings show T-lymphocyte recruitment into the intestine, which is determined by an increase in the expression of $\beta 7$ integrin in the blood-activated T-lymphocytes and the MAdCAM-1 molecule in the colon. This corresponds to the fact that, as regards the intestine, they present high levels of T-lymphocytes, both CD4+ and $\mathrm{CD} 8+$. The majority (70-99\%) of all the isolated $\mathrm{T}$ cells in the colonic mucosa have a CD4+CD45RA- (immunological memory) phenotype.

The results of the variation in the number of intestinal lymphocytes and MC determine that there is a geographical area of maximum alteration of those between the terminal ileum and descending colon, even though this does not mean that the remaining intestinal regions cannot also present alterations in these cell levels.

In addition, in these patients an increase in IE lymphocytes in the area included between the jejunum and the descending colon is described.

The study of LP lymphocytes does not allow a particular behavioral pattern of these cells in patients with IBS to be established. Although an alteration in these lymphocytes is observed, their type cannot be defined clearly nor can the region of the intestine in which it occurs, and a generalization cannot be established. It has been suggested that the alterations in the levels of these lymphocytes could lead to maintaining underlying proinflammatory activity.

The MC are largely distributed in close proximity to the nerve endings in the intestinal mucosa in patients with IBS. When inflammation occurs, their number and proximity to the nerve endings increase, making them almost synaptic.

Further in-depth analysis of the cell alterations found is necessary, undertaking prospective studies that are well-designed, planned and managed with this objective in mind. Only then can the degree of involvement of the immune system in the pathophysiology of this disorder, which is as frequent as it is unknown in our environment, be determined.

\section{REFERENCES}

1. Thompson WG, Dotevall G, Drossman DA, Heaton KW, Kruis W Irritable bowel syndrome: guidelines for the diagnosis. Gastroenterol Int 1989; 2 (2): 92-5

2. Camilleri M, Heading RC, Thompson WG. Consensus report: Clinical perspectives, mechanisms, diagnosis and management of irritable bowel syndrome. Aliment Pharmacol Ther 2002; 16(8): 1407-30.

3. Morris-Yates A, Talley NJ, Boyce PM, Nandurkar S, Andrews G. Evidence of a genetic contribution to functional bowel disorder. Am J Gastroenterol 1998; 93 (8): 1311-7.

4. Zárate N, Mearin F. Síndrome del intestino irritable: Alteraciones motoras y correlación clínica. Med Clin (Barc) -Monografía- 2003; 4: 19-23.

5. Rey E, Díaz-Rubio M. Alteraciones de la sensibilidad visceral en el síndrome del intestino irritable. Med Clin (Barc) -Monografía2003; 4: 24-6.

6. Spiller RC. Postinfectious irritable bowel syndrome. Gastroenterology $2003 ; 124(6)$ : 1662- 71 .

7. Barbara G, De Giorgio R, Stanghellini V, Cremon C, Salvioli B, Corinaldesi R. New pathophysiological mechanisms in irritable bowel syndrome. Aliment Pharmacol Ther 2004; 20(Suppl 2): 1-9.

8. Talley NJ, Helgesen S, Zinsmeister AR. Are sexual and physical abuse linked to functional gastrointestinal disorders? Gastroenterology 1992; 102: 52 .

9. Pimentel M, Chow EJ, Lin HC. Eradication of small intestinal bacterial overgrowth reduces symptoms of irritable bowel syndrome. Am J Gastroenterol 2000; 95(12): 3503-6.

10. Arebi N, Gurmany S, Bullas D, Hobson A, Stagg A, Kamm M. Review article: The psychoneuroimmunology of irritable bowel syndrome - an exploration of interactions between psychological, neurological and immunological observations. Aliment Pharmacol Ther 2008; 28(7): 830-40.

11. Ramos Linares V, Rivero Burón R, Piqueras Rodríguez JA, García López LJ, Oblitas Guadalupe LA. Psiconeuroinmunología: conexiones entre sistema nervioso y sistema inmune. Suma Psicológica 2008; 15 (1): 115-42.

12. Clarke M, Oxman AD, editores. Formulating the problem. Manual del Revisor Cochrane 4.1.6 [actualización enero 2003]. Section 4 En: The Cochrane Library, Número 1, 2003. Oxford: Update Software. Actualizado trimestralmente.

13. Higgins JPT, Green S (editors). Cochrane Handbook for Systematic Reviews of Interventions Version 5.0.1. [updated September 2008] The Cochrane Collaboration, 2008. Available from www.cochranehandbook.org.

14. Dunlop SP, Jenkins D, Neal KR, Naesdal J, Borgaonker M, Collins $\mathrm{SM}$, et al. Randomized, double-blind, placebo-controlled trial of prednisolone in post-infectious irritable bowel syndrome. Aliment Pharmacol Ther 2003; 18 (1): 77-84.

15. Swiatkowski M, Rybakowski JK. Depression and T lymphocytes in patients with irritable bowel syndrome. J Affect Disord 1993; 28 (3): 199-202.

16. Weston AP, Biddle WL, Bhatia PS, Miner PB Jr. Terminal ileal mucosal mast cells in irritable bowel syndrome. Dig Dis Sci 1993; 38 (9): 1590-5.

17. O'Sullivan M, Clayton N, Breslin NP, Harman I, Bountra C, McLaren A, et al. Increased mast cells in the irritable bowel syndrome. Neurogastroenterol Motil 2000; 12 (5): 449-57.

18. Spiller RC, Jenkins D, Thornley JP, Hebden JM, Wright T, Skinner $\mathrm{M}$, et al. Increased rectal mucosal enteroendocrine cells, T lymphocytes, and increased gut permeability following acute Campylobacter enteritis and in post-dysenteric irritable bowel syndrome. Gut 2000 47 (6): 804-11.

19. Chadwick VS, Chen W, Shu D, Paulus B, Bethwaite P, Tie A, et al. Activation of the mucosal immune system in irritable bowel syndrome. Gastroenterology 2002; 122 (7): 1778-83.

20. Park CH, Joo YE, Choi SK, Rew JS, Kim SJ, Lee MC. Activated mast cells infiltrate in close proximity to enteric nerves in diarrheapredominant irritable bowel syndrome. J Korean Med Sci 2003; 18 (2): 204-10.

21. Dunlop SP, Jenkins D, Spiller RC. Distinctive clinical, psychological, and histological features of postinfective irritable bowel syn- 
drome. Am J Gastroenterol 2003; 98 (7): 1578-83.

22. Dunlop SP, Jenkins D, Neal KR, Spiller RC. Relative importance of enterochromaffin cell hyperplasia, anxiety, and depression in postinfectious IBS. Gastroenterology 2003; 125 (6): 1651-9.

23. Wang LH, Fang XC, Pan GZ. Bacillary dysentery as a causative factor of irritable bowel syndrome and its pathogenesis. Gut 2004; 53 (8): 1096-101.

24. Barbara G, Stanghellini V, De Giorgio R, Cremon C, Cottrell GS, Santini $\mathrm{D}$, et al. Activated mast cells in proximity to colonic nerves correlate with abdominal pain in irritable bowel syndrome. Gastroenterology 2004; 126 (3): 693-702.

25. Elsenbruch S, Holtmann G, Oezcan D, Lysson A, Janssen O, Goebel MU, et al. Are there alterations of neuroendocrine and cellular immune responses to nutrients in women with irritable bowel syndrome? Am J Gastroenterol 2004; 99 (4): 703-10.

26. Dong WZ, Zou DW, Li ZS, Zou XP, Zhu AY, Xu GM, et al. Study of visceral hypersensitivity in irritable bowel syndrome. Chin J Dig Dis 2004; 5 (3): 103-9.

27. Tunc B, Filik L, Altintaş E, Turhan N, Ulker A, Dağli U. Mucosal mast cells in irritable bowel syndrome and inflammatory bowel disease. Acta Medica (Hradec Kralove) 2005; 48 (3-4): 163-4.

28. Öhman L, Isaksson S, Lundgren A, Simrén M, Sjövall H. A controlled study of colonic immune activity and beta7+ blood T lymphocytes in patients with irritable bowel syndrome. Clin Gastroenterol Hepatol 2005; 3 (10): 980-6.

29. Park JH, Rhee PL, Kim HS, Lee JH, Kim YH, Kim JJ, et al. Mucosal mast cell counts correlate with visceral hypersensitivity in patients with diarrhea predominant irritable bowel syndrome. J Gastroenterol Hepatol 2006; 21 (1 Pt 1): 71-8.

30. Guilarte M, Santos J, de Torres I, Alonso C, Vicario M, Ramos L, et al. Diarrhoea-predominant IBS patients show mast cell activation and hyperplasia in the jejunum. Gut 2007; 56 (2): 203-9.

31. Holmén N, Isaksson S, Simrén M, Sjövall H, Öhman L. CD4+CD25+ regulatory $\mathrm{T}$ cells in irritable bowel syndrome patients. Neurogastroenterol Motil 2007; 19 (2): 119-25.

32. Remes-Troche JM, Adames K, Castillo-Rodal AI, Ramírez T, Barreto-Zuñiga $\mathrm{R}$, López-Vidal Y,et al. Intraepithelial gammadelta+ lymphocytes: a comparative study between celiac disease, small intestinal bacterial overgrowth, and irritable bowel syndrome. J Clin Gastroenterol 2007; 41 (7): 671-6.

33. Wang SH, Dong L, Luo JY, Gong J, Li L, Lu XL, et al. Decreased expression of serotonin in the jejunum and increased numbers of mast cells in the terminal ileum in patients with irritable bowel syndrome. World J Gastroenterol 2007; 13 (45): 6041-7.

34. Akbar A, Yiangou Y, Facer P, Walters JR, Anand P, Ghosh S. Increased capsaicin receptor TRPV1-expressing sensory fibres in irritable bowel syndrome and their correlation with abdominal pain. Gut 2008; 57 (7): 923-9.

35. Piche T, Saint-Paul MC, Dainese R, Marine-Barjoan E, Iannelli A Montoya ML, et al. Mast cells and cellularity of the colonic mucosa correlated with fatigue and depression in irritable bowel syndrome. Gut 2008; 57 (4): 468-73.

36. Lee KJ, Kim YB, Kim JH, Kwon HC, Kim DK, Cho SW. The alteration of enterochromaffin cell, mast cell, and lamina propia $\mathrm{T}$ lymphocyte numbers in irritable bowel syndrome and its relationship with psychological factors. J Gastroenterol Hepatol 2008; 23 (11): 1689-94.

37. Cremon C, Gargano L, Morselli-Labate AM, Santini D, Cogliandro RF, De Giorgio R, et al. Mucosal immune activation in irritable bowel syndrome: gender-dependence and association with digestive symptoms. Am J Gastroenterol 2009; 104 (2): 392-400.

38. Kindt S, Van Oudenhove L, Broekaert D, Kasran A, Ceuppens JL, Bossuyt X, et al. Immune dysfunction in patients with functional gastrointestinal disorders. Neurogastroenterol Motil 2009; 21 (4): 389-98.

39. Öhman L, Isaksson S, Lindmark AC, Posserud I, Stotzer PO, Strid H, et al. T-cell activation in patients with irritable bowel syndrome. Am J Gastroenterol 2009; 104 (5): 1205-12.

40. Elenkov IJ, Chrousos GP. Stress Hormones, Th1/Th2 patterns, Pro/Anti-inflammatory Cytokines and Susceptibility to Disease Trends in Endocrinology and Metabolism 1999; 10 (9):359-68.

41. Vives Puiggròs J, Gallart T, Algarra López de Diego I, Blanca Gómez M, Fresno Escudero M, Garrido Torres-Puchol F, et al. Inmunología. En: Rozman C, Cardellach F. Medicina Interna. 16 ${ }^{\mathrm{a}}$ edición. Barcelona; 2008 